\title{
THE ROLE OF COMPUTED TOMOGRAPHY IN PLANNING SURGICAL TREATMENT OF PERITONEAL DISSEMINATION FROM OVARIAN CARCINOMA
}

\author{
Katarina Janković ${ }^{1}$, Jelena Janićijević ${ }^{1}$, Đorđije Šaranović ${ }^{2}$
}

${ }^{1}$ Medicinski fakultet Univerziteta u Beogradu

${ }^{2}$ Mentor; Klinika za digestivnu hirurgiju Kliničkog centra Srbije, Medicinski fakultet Univerziteta u Beogradu

Sažetak

Uvod: Karcinomi jajnika pokazuju sklonost ka peritonealnoj diseminaciji čija je primarna terapija hirurska a uspešan hirurški tretman zahteva sprovođenje citoreduktivne hirurgije i citoreduktivne intraperitonealne hemioterapije. Preoperativna radiološka dijagnostika abdomena i karlice (CT, MR, PET-CT) je značajna u smislu detekcije peritonealne karcinomatoze i postavljanja indikacije za hirurško lečenje.

Cilj rada: Ukazati na značaj tehnike CT pregleda u detekciji peritonealnih implanata i određivanja PCI (peritonealni kancer indeks).

Materijali i metode: Istraživanjem je obuhvaćena 21 pacijentkinja kod kojih je histopatološki verifikovan karcinom ovarijuma u periodu od januara 2014. do februara 2015. Populaciju čine pacijentkinje prosečne starosti 57 godina. Svi pregledi su učinjeni na 128-slajsnom Toshiba CT aparatu nakon peroralne pripreme i intravenske aplikacije kontrasta. Metodama deskriptivne statistike analizirani su stepen distenzije lumena tankog creva, veličina implanata u svim kvadrantima abdomena i na serozi tankog creva i ti nalazi su korelirani sa histopatološkom vrednošću PCI.

Rezultati: Svim pacijentima je preoperativno na osnovu CT pregleda merena veličina peritonealnih implanata i izračunat PCI (prosečna vrednost) kao i stepen distenzije 4 segmenta tankog creva i ti nalazi su korelirani sa histopatološkom vrednošću PCI. Pokazano je da distenzija lumena ima veliku ulogu jer je kompjuterizovana tomografija dala precizne podatke $\mathrm{u}$ pregledima $\mathrm{u}$ kojima je ostvarena adekvatna distenzija jer su tada šanse za pogrešno dijagnostikovanje svedene na minimum.

Zaključak: Radi bolje kvantifikacije peritonealne diseminacije a u cilju tačnijeg određivanja PCI potrebno je da tehnika CT pregleda abdomena i karlice bude prilagođena te je neophodno ostvariti dobru distenziju lumena tankog creva u cilju bolje detekcije peritonealnih implanata na serozi tankog creva.

Ključne reči: peritonealna diseminacija, karcinom jajnika, CT

\section{Abstract}

Introduction: Ovarian carcinomas primarily disseminate within the peritoneal cavity which their in the first line treatment is surgical. To make surgical treatment successful, it includes cytoreductive surgery and intraperitoneal chemotherapy. The role of abdominopelvic radiology exams in this case is to evaluate peritoneal carcinomatosis so that surgical treatment can be conducted.

Aim: To signify at computed tomography (CT) scan in detection of peritoneal carcinomatosis measured as the peritoneal carcinomatosis index(PCI).

Materials and methods: The study group consisted of 21 female patients in which it was histopathologically verified ovarian carcinoma starting from January 2014 to February 2015. Average age of group population is 57. All CT scanning examinations were performed with 128-slice Toshiba CT scanner after oral and intravenous administration of contrast material. The criteria for the identification of a peritoneal metastasis was the presence of a nodular, plaquelike, or infiltrative soft-tissue lesion in the peritoneal fat or on the peritoneal surface later compared with histopathological index of peritoneal carcinomatosis.

Conclusion: Although computed tomography does not always give full precise results its purpose is still useful in patient's evaluation with the suspicion of peritoneal dissemination especially in the absence of other more sensitive and accurate imaging modalities.

Keywords: peritoneal dissemination, ovary, carcinoma, CT 


\section{Introduction}

Ovarian cancer is the fifth most common malignancy in women and the most common gynecologic malignancy to cause death [1-4]. It usually affects women over the age of 60 [5]. The risk of ovarian cancer is higher in women with a family history of the disease $[1,5]$. Ninety percent of ovarian cancers are sporadic, and $10 \%$ of it are due to hereditary syndromes such as breast-ovarian cancer syndrome with mutations in BRCA1 and BRCA2 genes[1, 5.6.7].

Ovarian cancer is usually in an advanced stage at diagnosis due to the presence of peritoneal carcinomatosis, which develops as a result of peritoneal fluid circulation. Peritoneal seeding is the most common pathway for the spread of ovarian cancer. Because $90 \%$ of ovarian cancers are surface epithelial carcinomas, the tumor cells are able to slough off the ovary and enter the peritoneal circulation, thereby seeding multiple sites [1].

Several methods of visualization are used as a preoperative examination of the tumor extensiveness, such as ultrasound [8], computed tomography, magnetic resonance imaging( MRI) and F - 18 FDG - positron emission tomography (PET/CT) [9-11]. Data obtained by computed tomography and magnetic resonance imaging are similar according to previous researches, but computed tomography has the advantage of shorter protocol, lower price and it is more available in most of healtcare institutions [9].

To achieve a detailed location, 13 abdominopelvic regions are accessed. Nine of the regions are defined by the intersection of two transverse and two sagittal planes that divide the abdomen into nine equal sized abdominopelvic regions. The two transversal planes are the lowest aspect of the costal margin and the line that connects the two spinae illiacae anteriores. The two sagittal planes are defined as the mid-clavicular lines billaterally. With this grid, nine equal sized regions are accurately described. The small bowel is assessed using four additional abdominopelvic regions, designated abdominal regions 9 to 12 , beginning on the upper jejunum and continuing to the lower ileum. After exploring the abdomen and pelvis for peritoneal implants the lesion size score (LS) is used to form the PCI (Table1). An LS-0 score means that no

Table 1. PCI system based on lesion size score

Lesion size score

LS 0 No tumor seen

LS 1 Tumor up to $0.5 \mathrm{~cm}$

LS 2 Tumor up to $5.0 \mathrm{~cm}$

LS 3 Tumor $>5.0 \mathrm{~cm}$ or confluence malignant deposits are visualized. An LS-1 score signifies that tumor nodules less than $0.5 \mathrm{~cm}$ in greatest dimension are present. An LS-2 score signifies tumor nodules between 0.5 and $5.0 \mathrm{~cm}$ present. LS-3 signifies tumor nodules greater than $5.0 \mathrm{~cm}$ in any dimension present. If there is a confluence of tumor, the lesion size is scored as 3 [12].

Peritoneal implants are soft-tissue masses that appear as solitary or multiple nodules. The nodules can coalesce to form plaques that coat the viscera. These plaques appear as areas of irregular soft-tissue thickening. Omental cake refers to tumor infiltration of greater omentum and is usually of soft tissue density but can also calcify. Common sites of metastases include the right hemidiaphragm, liver, right paracolic gutter, bowel, omentum, and pelvis. In the pelvis, implants can involve the superior surface of the sigmoid, the sigmoid mesocolon, the uterosacral ligaments lateral to the rectum, and the pelvic sidewall, bladder, rectum, and inguinal canals [1].

Treatment of peritoneal surface malignancy involves cytoreductive surgery and intraperitoneal perioperative hyperthermic chemotherapy. Cytoreductive surgery reduces carcinomatosis to microscopic residual disease so that intraperitoneal hyperthermic chemotherapy is able to eradicate cancer[14-17].

Preoperative CT PCI is used to evaluate the extensiveness of peritoneal carcinomatosis so that optimal treatment can be conducted [18].

\section{Materials and methods}

Abdominal and pelvic computed tomography were perfomed and evaluated retrospectively in patients with peritoneal carcinomatosis in whom the primary tumor was ovarian carcinoma. The study group formed $21 \mathrm{fe}$ male patients with histopathologically confimed ovarian carcinoma in period starting from January 2014 to February 2015. Age of population is from 40 to 85 (table2).

Table 2. Patient characteristics

\begin{tabular}{|l|l|}
\hline $\begin{array}{l}\text { Age 40-85 (average 57) } \\
\text { Sex - female }\end{array}$ & $\begin{array}{l}\text { Patient } \\
\text { characteristics } \\
(\mathbf{n}=\mathbf{2 1})\end{array}$ \\
$\begin{array}{l}\text { Primary tumor - ovary } \\
\text { Histology - mucinous }\end{array}$ & \\
\hline $\begin{array}{l}\text { Treatment - cytoreductive } \\
\text { surgery, intraperitoneal } \\
\text { chemotherapy }\end{array}$ & \\
\hline
\end{tabular}


Preoperative scanning was conducted on these patients at Rendgen department of First surgical clinic of Clinical Centre of Serbia. All were examined with 128-slice Toshiba CT scan after peroral preparation and intravenous application of contrast. Peroral preparation included $1500 \mathrm{ml}$ of water one hour earlier plus $500 \mathrm{ml}$ water immediately before the scanning. Optiray 350 contrast agent was injected in a dose of $1 \mathrm{ml} / \mathrm{kg}$ body weight. Scanning was performed in portal-vein fase with scan delay of 60 seconds. Reconstruction included 1-mm thick slices in axial, coronal and sagittal plane. The criteria for the identification of a peritoneal metastasis was presence of a nodular, plaquelike, or infiltrative soft-tissue lesion in the peritoneal fat or on the peritoneal surface later compared with histopathological PCI. We classified these values into three categories: low (PCI 0-10), moderate (PCI 11-20) and high (PCI >21).
For the analysis of primary data descriptive statistical methods and the methods for dependency were used. Descriptive statistical methods included measures of central tendency (mean), measures of variability (standard deviation) and the relative numbers (structure indicators). The method used for analysis of dependance is the Spearman rank correlation coefficient. The statistical hypotheses were tested at the level of statistical significance (alpha level) of 0.05 .

\section{Results}

Histopathological PCI had the following results: 1 value of low PCI, 8 values of moderate PCI and 12 high PCI score. This study gave the next results: 4 cases with low PCI, 11 with moderate and 6 results of high PCI. Of these 21 cases, 13 cases (62\%) were accurately classified

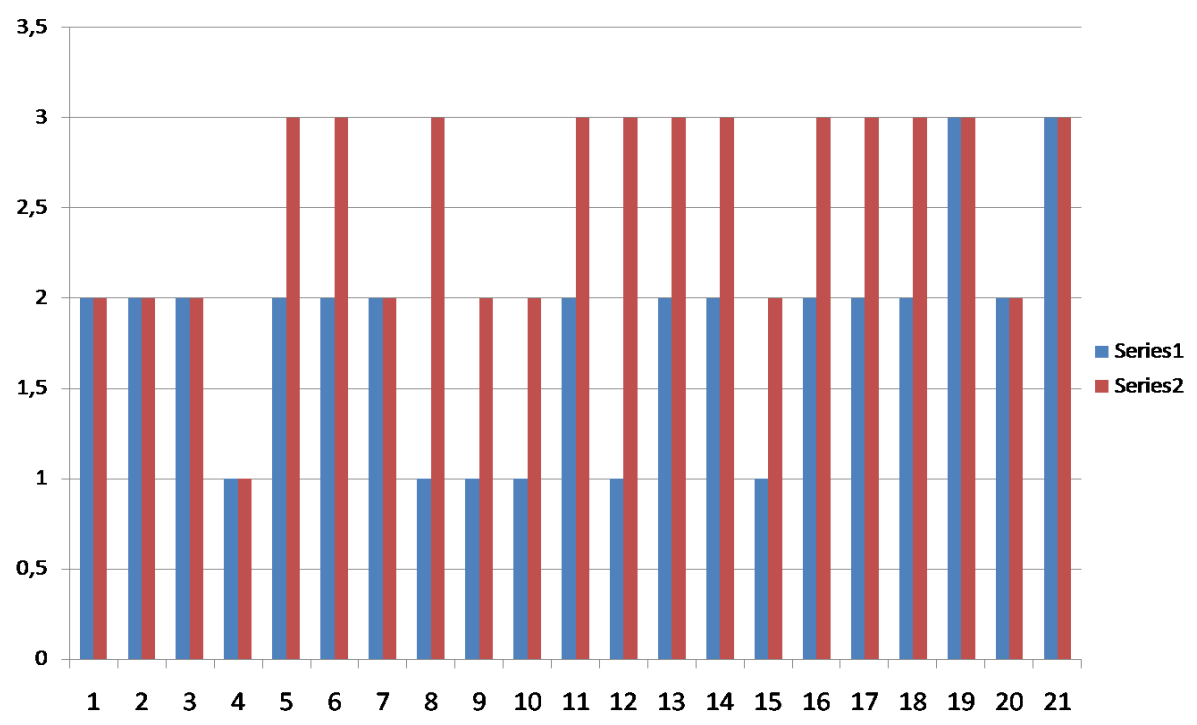

Chart 1. Comparison of ctPCI and hpPCI

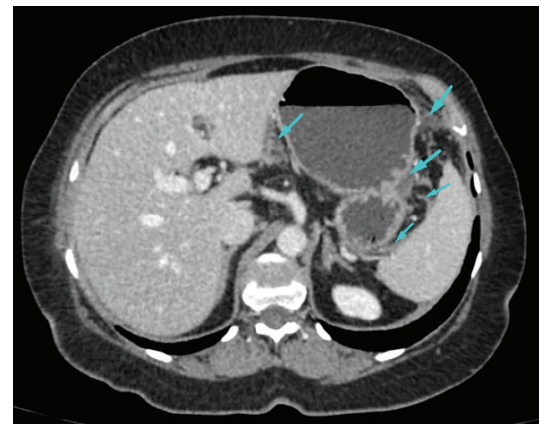

Figure 1. CT scan of a 54-year-old patient shows metastatic implants and nodules (arrow).

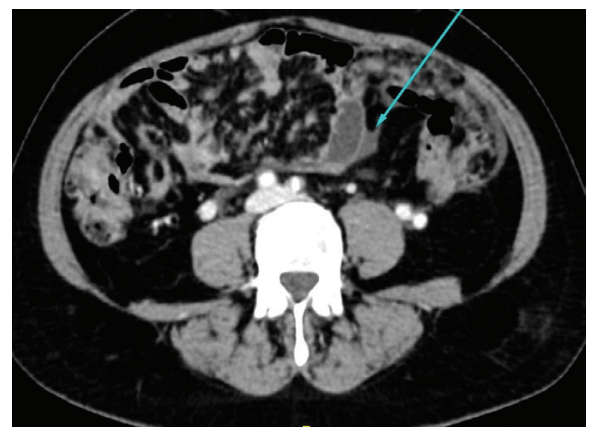

Figure 2. CT image of a 49-year-old patient with a complete concordance about the PCI values between CT and histopathologic data (PCI value $=21$ ). The CT examination shows peritoneal implant on serosa of distal jejunum.

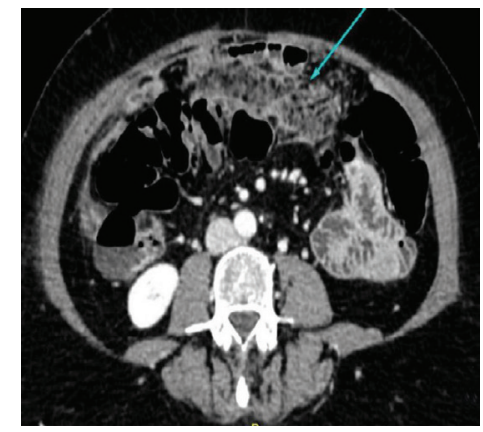

Figure 3. CT image of a 57-year-old patient with high PCI score, $(\mathrm{CT}$ value $=$ 22 , HP value $=25$ ). The CT examination shows abnormal thickening of the greater omentum, which appears as omental cake (arrow). 
into the categories by the CT PCI when compared with histopathological PCI (Chart 1). According to Spearman rank correlation, there is statistically moderate-good significance of hpPCI and ctPCI correlation ( $\mathrm{rs}=0,543$; $p=0,011$ ). Average age of our patients is $57,6 \pm 10,1$. Figures 1,2 and 3 are demonstrating varying peritoneal implants we found in this study.

\section{Discussion}

There is no universally accepted reference standard for imaging of peritoneal carcinomatosis[19]. Preoperative $\mathrm{CT}$ of the abdomen and pelvis play an integral role in determining the extent of peritoneal and visceral disease in patients being considered for cytoreductive surgery and intraperitoneal chemotherapy for appendiceal, ovarian, colorectal, primary peritoneal, gastric, mesothelioma, and other rare types of gastrointestinal disease involving the peritoneum. Careful patient selection based on preoperative imaging may prevent unnecessary surgeries in patients whose tumors are too extensive and cannot be adequately cytoreduced[20]. Of these 21 cases, 13 cases $(62 \%)$ were accurately classified into the categories by the CT PCI when compared with histopathological PCI in our study. According to studies we analized, classifying was more accurate but still poor. In their research concordance was found in $34(65 \%)$ cases of 52[21]. These authors state that the sensitivity of CT in detecting peritoneal implants was influenced by lesion size and that CT PCI significantly underestimates the intraoperative PCI. In the next study the observer independently determined the PCI for MR and CT. Compared with surgical PCI, MRI correctly categorized tumor volume in $20(91 \%)$ of 22 patients. CT correctly categorized tumor volume in 11 of 22 (50\%) patients. According to authors, CT is characterized by its limited soft tissue contrast. On all imaging studies, soft-tissue contrast allows one to distinguish between tumors from adjacent and the normal tissues. With CT, small peritoneal tumors may be indistinguishable from the surrounding tissues, resulting in reduced sensitivity for peritoneal carcinomatosis. MR imaging uses different types of image contrast to produce images that are more sensitive for showing peritoneal tumors[20].

Although computed tomography does not always give full precise results its purpose is still useful in patient evaluation with the suspicion of peritoneal dissemination especially in the absence of other more sensitive and accurate imaging modalities.

\section{References}

1. Pannu HK, Bristow RE, Montz FJ, Fishman EK. . Multidetector CT of peritoneal carcinomatosis from ovarian cancer. Radiographics. 2003;23:687-670.

2. Parkin DM, Bray F, Ferlay J, Pisani P. Global cancer statistics. CA Cancer J Clin. 2002;55:74-108.

3. J. A. Ledermann, F. A. Raja, C. Fotopoulou, A. Gonzalez-Martin, N. Colombo, C. Sessa. Newly diagnosed and relapsed epithelial ovarian carcinoma: ESMO Clinical Practice Guidelines for diagnosis, treatment and follow-up. Ann Oncol 2013; 24 (Suppl 6): vi24-vi32

4. Stuart GC, Kitchener H, Bacon M, et al. 2010 Gynecologic Cancer Intergroup (GCIG) consensus statement on clinical trials in ovarian cancer: report from Fourth Ovarian Cancer Consensus Conference. Int J Gynecol Cancer 2011;21:750-5. 5. Henry T. Lynch, Murray Joseph Casey, Carrie L. Snyder, Chhanda Bewtra, Jane F. Lynch, Matthew Butts et al. Hereditary ovarian carcinoma: Heterogeneity, molecular genetics, pathology, and management. 2009;2(3):97-137

6. A. Antoniou, P.D.P. Pharoah, S. Narod, H.A. Risch, J.E. Eyfjord, J.L. Hopper et al. Average Risks of Breast and Ovarian Cancer Associated with BRCA1 or BRCA2 Mutations Detected in Case Series Unselected for Family History: A Combined Analysis of 22 Studies. Am J Hum Genet. 2003;72(5):1117-30

7. T S Frank, S A Manley, O I Olopade, S Cummings, J E Garber, B Bernhardt et al. Sequence analysis of BRCA1 and BRCA2: correlation of mutations with family history and ovarian cancer risk. J Clin Oncol. 1998;16(7):2417-25.

8. A. C. Testa, M. Ludovisi, F. Mascilini, A. Di Legge, M. Malaggese, A. Fagottiesta et al. Ultrasound evaluation of intra-abdominal sites of disease to predict the likelihood of suboptimal cytoreduction in advanced ovarian cancer: a prospective study. Ultrasound Obstet Gynecol 2012; 39: 99-105

9. Forstner R. Radiological staging of ovarian cancer: imaging findings and contribution of CT and MRI. Eur Radiol 2007; 17: 3223-3246

10. Funicelli L, Travaini LL, Landoni F et al. Peritoneal carcinomatosis from ovarian cancer: the role of CT and [18F] FDG-PET/CT. Abdom Imaging 2010; 35: 701-707

11. Forstner, R., Chen, M. and Hricak, H., Imaging of ovarian cancer. J. Magn. Reson. Imaging, 1995; 5: 606-613

12. Rhonda L Harmon, Paul H Sugarbaker.Prognostic indicators in peritoneal carcinomatosis from gastrointestinal cancer. Int Semin Surg Oncol. 2005; 2: 3.

13. Gabriele Masselli. ISRN Pathology Volume 2013 (2013), Small Bowel Imaging: Clinical Applications of the Different Imaging Modalities-A Comprehensive Review

14. Tomoyoshi Aoyagi, Krista P Terracina, Ali Raza, and Kazuaki Takabe. Current treatment options for colon cancer peritoneal carcinomatosis. World J Gastroenterol. 2014; 20(35): 12493-12500.

15. Mátrai Z, Péley G, Kovács T, Rényi VF, Szívós E, Szabó E. Cytoreductive surgery and intraperitoneal hyperthermic chemoperfusion for peritoneal carcinomatosis 
caused by recurrent inflammatory myofibroblastic sarcoma: a case report and review of the literature. Orv Hetil. 2006;147(4):147-58.

16. Sung Joon Bae, Ui Sup Shin, Young-Jun Ki, Sang Sik Cho, Sun Mi Moon, and Sun Hoo Park. Role of Peritoneal Lavage Cytology and Prediction of Prognosis and Peritoneal Recurrence After Curative Surgery for Colorectal Cancer. Ann Coloproctol. 2014 Dec; 30(6): 266-273.

17. Esquivel J, Sticca R, Sugarbaker P, Levine E, Yan T, Alexander $\mathrm{R}$, et al. Cytoreductive surgery and hyperthermic intraperitoneal chemotherapy in the management of peritoneal surface malignancies of colonic origin: a consensus statement Society of Surgical Oncology. Ann Surg Oncol. 2007;14(1):128-33.
18. Rhonda L Harmon, Paul H Sugarbaker, Prognostic indicators in peritoneal carcinomatosis from gastrointestinal cancer, Int Semin Surg Oncol. 2005; 2: 3.

19. Dirisamer A, Schima W, Heinisch M. Detection of histologically proven peritoneal carcinomatosis with fused 18F-FDG-PET/MDCT. Eur J Radiol. 2009;69: 536-541

20. Low RN, Barone RM, Lucero J. Comparison of MRI and CT for Predicting the Peritoneal Cancer Index. Ann Surg Oncol. 2015;5(22):1708-1715.

21. Jesus Esquivel, Terence C. Chua. CT Versus Intraoperative Peritoneal Cancer Index in Colorectal Cancer Peritoneal Carcinomatosis: Importance of the Difference Between Statistical Significance and Clinical Relevance, Ann Surg Oncol. 2009;16:2662-2663 